\title{
The Roots of Slovak Utopianism and Utopian Concepts of 1848
}

\author{
LUKÁŠ PERNÝ \\ Institute of Philosophy, Faculty of Arts, University of Prešov, UI. 17. Novembra č. 1, Prešov, 08001 , Slovakia \\ Email: lukas.perny@smail.unipo.sk
}

\begin{abstract}
Slovak utopianism (and specific social and political philosophy) of the 19th century are unique topics for philosophical research that can be useful especially in an international context. The aim of the research is, using the comparative method, to create a basic overview of utopian concepts of the 19th century in Slovakia in order to highlight their implementation today. The study consists of the following topics: 1) the influence of German philosophy of history (Hegel, Herder, Schelling) on social and political conceptions of the nation and the synthesis of German philosophical influence in the Slovak philosophical context (Kollár, Šafárik, Štúr) and 2) socio-philosophical concepts related to the role of Slovaks in the international context (Feješ, Daxner). The Slovak national utopia, in the form of enforcing the cultural and social rights of Slovaks in their own sovereign state, was partially fulfilled until the 20th century (by the establishment of Czechoslovakia and later by the establishment of the independent Slovak Republic). The Constitution of the Slovak Republic is the proof that originally social utopian visions, that seemed naive and impossible to achieve in the 19th century, became a reality of political practice in the 20th century.
\end{abstract}

Keywords: social philosophy, political philosophy, slovak utopianism, V̌̌eslávie’s generation, Štúr's group, Ján Kollár, Pavol Jozef Šafárik, Ludovít Štúr, Ján Feješ, Štefan Marko Daxner

\section{INTRODUCTION}

The main topic of the presented work will be the analysis and interpretations of utopian concepts of Slovak social and political philosophy of the 19th century (concepts of Kollár, Šafárik, Štúr, Feješ and Daxner) in the context of the current state identity of Slovaks (in the Constitution of the Slovak Republic). The presented study consists of research in the field of social philosophy, political philosophy and philosophy of history and uses an analytical and comparative method with primary (Slovak articles and books from the 19th century) and secondary sources (interpretations of selected experts for this topic). In the scientific context of the presented topic there are only a few indexed articles in the Web of Science and Scopus (Veselá 2016; Maxwell 2018; Odlerová, Hyllova 2019; Gluchman 2020; Valco et al. 2020), many more studies on the topic have been published outside of indexed sources (Várossová 1969; Bodnár 1987; Pichler 2006; Hajko 2007; Dupkala 2009; 
Brock 2012; Nedashkovskaya, Myagkov 2017; Hajko 2018). The topic is very little reflected in the international context and the presented study is an introduction for possible further, more detailed studies.

\section{SLOVAK UTOPIANISM AND THE HISTORY OF PHILOSOPHIZING IN SLOVAKIA}

Before analysing the problem of Slovak social utopianism, in accordance with the researches of R. Dupkala and the authors who dealt in detail with this topic like J. Bodnár, V. Bakoš, T. Pichler, T. Münz and others (see Dupkala 2009: 554; Bilasová et al. 2004; Bodnár 1987), it is necessary to distinguish the history of philosophizing in Slovakia and specifically Slovak philosophy (Dupkala, Perny 2020). While the history of philosophizing in Slovakia has significantly older roots, ${ }^{1}$ typically Slovak philosophy originated mainly in the late 18th and in the 19th century. J. M. Hurban wrote about Slovak philosophy for the first time in the magazine Slovenské pohlady (Slovak Views) (Hurban 1847). Following the studies of D. Hajko, the first Slovak philosophers were Š. M. Daxner and L. Štúr (Hajko 2019). The term Slovak utopianism - which I present as socio-philosophical theories based on the anticipation ${ }^{2}$ of the future state of the (ideal ${ }^{3}$ ) political system for Slovak life and institutions - follows the theory of utopia expert J. Szacky who in the context of the 19th century writes about utopias of romanticism and national utopias (Szacki 1971). National utopias, in contrast to global utopias, are focused primarily on finding the ideal state primarily for the nation. This concept originated in the romantic period as part of the processes of emancipation of nations in Europe, but their roots can be traced back to the enlightenment (Rousseau's Du contrat social). Slovak utopianism and Slovak social and political philosophy cannot be considered without influence of the philosophy of history, which Slovak national thinkers (see Img. 1 and 2) adopted mainly from the German philosophical tradition (Herder 1941; Herder 1968; Hegel 1989), but also from Russian or Polish messianism, which was extensively studied by R. Dupkala (Dupkala 2003). Slovak utopianism and Slovak national philosophy are specific, especially that it is not present only in philosophical writings, but we can find philosophical visions fragmentarily in the memorandums, political speeches, national requests, art and literature (prose and poetry). ${ }^{4}$ Examples of Slovak utopianism, e.g. Ján Hollýs utopian idealization of Great Moravia as the form of Golden Age ${ }^{5}$ in Svätopluk and Sláv $v^{6}$ or

1 The first foundations of philosophizing in Slovakia can be found in the tradition of Saints Cyril and Methodius, who formulated one of the first definitions of philosophy in the Slavic language (see more in the interview (Dupkala, Perný 2020)).

2 The term anticipation follows the author H. G. Wells, who in his work The Modern Utopia described utopias, utopians and visionaries of future reality, including himself, as manifestations of anticipation (Wells 1905: 9).

3 Ideal in the context of finding the best vision of social reality.

4 The diversity and scope of Slovak and Czech utopianism was perfectly documented by G. Ždárský in his brief annotations of Czech and Slovak poetry and prose (Ždárský 1924; Veselá 2016). The influence of philosophy can be found, for example, in the poetry of Slovak revolutionary and poet Janko Král (Vongrej 1989; Kraus 1984) or the poetry of Slovak messianist Samuel Bohdán Hroboň (Dupkala 2000).

5 In general, the history of utopianism (in various historical periods) refers to the lost golden age, which is transformed into different cultures, religions or ideological movements through specific projections.

6 Svätopluk (1833) (Hollý 1999) is a poetry work with heroic and mythological verses about Svätopluk, ruler of Great Moravia. J. Hollý considered the Slovak nation to be the core of the Svätopluk's Empire and the Slovaks to be the direct followers of Great Moravia (the first major state that was predominantly West Slavic to emerge in the area of Central Europe). Sláv (Eng. The Glory) is a historical epic about the idea of Slavic unity (Hollý 1950). 




Img. 1. Slovak national thinkers. The source is školské.sk

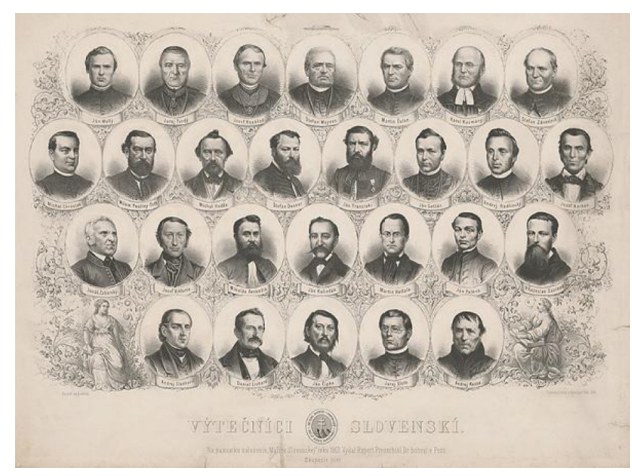

Img. 2. Slovak national awakeners ('Výtečníci slovenski'). The source is the Slovak National Gallery

Kollar's and Štúr's visions of Slavic past and future (in The Daughter of Sláva and The Slavdom and the World of the Future $e^{8}$ ), Daxner's and Feješs vision of reconciliation of nations through a social contract (Feješ 1981; Daxner 1958), activities of religious reconciliation under Moyzes and Kuzmány ${ }^{9}$ or political articles by P. J. Šafárik (national requests, memorandums) (Šafárik 1963) are specific manifestations of utopianism in the Slovak and Slavic context. A widespread manifestation of Slavic utopianism are the following: 1) utopia of the past - romantic idealization of Slavic communities (obshchina or mir $^{10}$ as a specific form of ideal commonwealth) and 2) utopia of the future - messianic vision of Slavic unity as a utopian project of future (philosophy of history). All these visions, works, ideas and creations can be assigned with the adjective Slovak utopianism and in a broader context of Slavic nations with the adjective Slavic utopianism. Slovak utopianism as a form of national utopia also has international tendencies (global utopia), in the context of highlighting humanism and pacifism (peaceful coexistence between nations). But this coexistence is conditioned by the nation's right to sovereign self-determination (Feješ 1981; Daxner 1958). Slovak utopianism was formulated as part of the national movements in the 19th century, because especially Slovak romantic utopianism is primarily based on the ideological points of the national emancipation of Slovaks (Broock 2012; Pichler 2006; Dupkala 2000; Bilasová et al. 2004).

7 Slávy dcera (Eng. The Daughter of Sláva, 1824) (Kollár 2001; 2018) is a poetic work by J. Kollár; an epic poem written in the form of a sonnet; a national epic of all the Slavic people.

8 Slovanstvo a svet budúcnosti (Rus. Славянство и мир будущего, Germ. Das Slawenthum und die Welt der Zukunft, 1851) (Štúr 1993; 2015) is the final work of the Slovak patriot and ideological initiator of the national revolution of 1848, L. Štur. Štúr's concept argues with the programmatic text of the national revival of the Slavs of the first half of the 19th century (Kollár). Štur idealizes the Slavs, because they create a romantic vision of Slavic future and an idealistic image of Russia, which he considers as a state that will unite the Slavs. Štúr's work is critically against the Western culture, atheism and revolutions. According to Herder's linguistic model, he transforms language into a means of differentiation (see more Nedashkovskaya, Myagkov 2017).

9 The reconciliation of the Catholic and Lutheran branches through Štefan Moyzes and Karol Kuzmány (as a utopian act, in opposition to religious disputes) also contributed to the establishment of a unified Slovak philosophy and political vision as a basis for the emancipation process (see Novomeský 2019; Hajko 2018). The idea of synthesizing religious concepts in favour of a unified struggle for national emancipation became the dominant element of Slovak social and political philosophy.

${ }_{10}$ Rus. община, обчество, крестьянская община, мир; Eng. obshchina, mir, society. 


\section{JÁN KOLLÁR AND LUDOVIIT ŠTÚR}

Slovak social philosophy and Slovak philosophy of history were influenced by two German philosophers: Herder ${ }^{11}$ and Hegel ${ }^{12}$. The main and fundamental difference between Kollár's and Štúr's conception is that while Kollár preferred Slavic unity without recognizing Slovaks as an independent and unique nation, ${ }^{13}$ Štúr considered Slovaks to be an independent nation with the right to their own Slovak language and their own state. While Kollár considered the preference for Slovak interests to be a manifestation of the fragmentation of the Slavs, Štur considered Slovak national interests to be a priority.

Ján Kollár, together with P. J. Šafárik and other representatives of the generation of V̌seslávie (representing the idea of Slavonic mutuality), ${ }_{14}^{14}$ based their conception mainly on Herder, but were also influenced by the authors as Schelling, Fichte, Kant and others (Dupkala 2006: 76). In Kollár's conception, Herder's philosophy of history was transformed into the philosophy of history of humanism (anthropo-naturalistic conception of history developed with emphasis on Slavs). It means that in Kollar's conception - man, nation and society - are a triple subject of history. Kollár projects history as a socio-historical process based on the improvement of the spiritual principle. Historical-optimistic utopianism presupposes that humanity is improving, it must walk for goodness and the victory of law and justice (Kollár 1863). According to Kollár, the goal of humanity ${ }^{15}$ is to move forward, to develop; nations are part of the historical-creative process and the importance of a nation is determined by realization of humanity. Kollár projects a model of Slavic reciprocity, which is based primarily on the development of culture. Kollár fought primarily for the cultural autonomy of Slavs in the world of the 19th century, but he did not demand political rights. Other important person of V̌̌eslávie’s generation, Pavol Jozef Šafárik, also prefers idea of the history as a process of humanization of nations as a historical-creative element (Dupkala 2006: 84), but while Kollár radically rejected Slovak autonomy, Šafárik was opened to the ideas of the rights of Slovaks for self-determination. Šafárik characterizes the Slavs as religious-minded, hard-working, cheerful, hospitable and peaceful (Šafárik 1963: 71-72), but also internally inconsistent, disputed and accepting foreign influence (from Western nations especially).

Finally, Ludovít Štúr can undoubtedly be described as the most important Slovak national awakener and philosopher. L. Štúr proposed several social and political models within the framework of national emancipation. He started with the concept of Austroslavism (which failed after the unsuccessful national revolution of 1848) and completed his philosophy of history with the vision of a unified Slavdom (Pan-Slavism) led by Russia and the Eastern Orthodox Church. Štúr's ideas about society can generally be divided into three periods:

${ }^{11}$ Herder's inspiration (Herder 1941; Herder 1968) appears (see Dupkala 2006: 76-87) in Kollár's conception of Slavic unity (Kollár 1954), which, as Vladimír Clementis recalls (Clementis 1946), is based on the unification of Slavs through culture and art.

12 Štúr's political conception of national emancipation, influenced by Hegel (Hegel 1989) can be found in his political speeches and in his final work The Slavdom and the World of the Future (Štúr 2015). Štúr was most influenced by Hegel's works: The Phenomenology of the Spirit (1807), Lectures on the Philosophy of History (1837), Elements of the Philosophy of Right (1820), Science of Logic (1816) and Lectures on Aesthetics (1835), notes R. Dupkala (Dupkala 2006: 109).

${ }^{13}$ Kollár recognized only the Czechoslovak identity and Slovakized Czech language; finally, T. G. Masaryk, President, and founder of Czechoslovakia (the first state of Czech and Slovaks after the World War I in 1919), followed Kollár and Czechoslovakism.

14 V̌seslávie’s generation include personalities: P. J. Šafárik, J. Kollár, F. Palacký and K. Kuzmány (Timura 2018).

15 Ján Kollár as a humanist, actively opposing capital punishment (Gluchman 2020). 
1. The pre-revolutionary period (until 1848) of promoting the concept of Austroslavism;

2. The revolutionary period (1848-1849) of radical democracy;

3. The post-revolutionary period (after 1849) of reformist conservatism.

Both Pichler and Walicki agree that Štúr was one of the conservative utopians, as he later followed Slavianophiles such as Kiréevskiy (Кире́евский), Chomakov (Чомаков), and Aksakov (Ака́ков) (Pichler 2006). According to Dupkala, the Štúr's vision of Russia as a country of the future implied Hegel's inspirations: 'It is known that Hegel mentioned Russia in a letter to Baron Uexküll as' the country of the future' (Dupkala 2006: 120). At the same time, the thesis was based on the concept of Hegel's philosophy of history, which Štúr applied to the history of the Slavs (the nations of the West have already fulfilled their historical mission, their spirituality has been exhausted and so the Slavic people are entering the scene of history, waiting for their historical fulfilment). In the Štúr's personality we can find a Hegelian revolutionary democrat, but also a conservative pan-Slavist who, under the influence of Slavianophiles (and Messianists ${ }^{16}$ ), presupposes the realization of the message of Jesus Christ by Slavic nations. Štur projects three possibilities for fulfilling the historical mission, political liberation and state independence of Slovaks: 1) Slavic Federation, 2) Austroslavism and 3) connection with the Russian empire. Štúr prefers the last alternative because 'Russians are the only Slavs who have preserved state independence'. (Štúr 1993: 157). This is influence of Hegel's philosophy of history. Utopia of the past (in Štúr's utopianism) is the idealized Slavic community-obshchina or mir (Štúr 2015). Szacki recalls that the romanticism gave birth to a new utopia of the past in the concept of obshchina or mir. This utopia of pre-feudal society became popular as a critique of feudal conditions, but also as a critique of Western capitalism. It referred to a national tradition that embodied an authentic democratic ideal (Szacki 1971: 54). This utopian concept spread in Poland, Russia, but also in Slovakia and the Czech Republic. According to Štúr, obshchinas existed in some parts of Russia in the 19th century. Štúr appreciated the solidarity, equality, inclination towards the family and respect for the elderly, who had authority in the obshchinas. Obshchina is axiologically based on family, traditions, solidarity between people and authority of older people. Economically, obschina is based on the collective ownership of lands and a strong cooperative principle. Štúr also projects the vision of educational reform (literacy as a prerequisite for civic engagement) and practically initiated the so-called folk schools (Germ. Volksschule) and evening schools. Together with Štúr, follow-up concepts were developed by thinkers from the so-called Štúr's group (Sk. Štúrova družina, štúrovci; see Img. 3), which included personalities such as Jozef Miloslav Hurban (Hurban 1944) and Michal Miloslav Hodža (Hodža 1847; Dupkala 2000). ${ }^{17}$ Philosophically, they followed Hegel's philosophy of history (Hegel 1989) and Herder's (Herder 1941; Herder 1968) idea about the peace-building mission of the Slavs. The following Herder's idea also had a great influence on the development of Slovak philosophy, especially the messianic line: 'The wheel of changing

${ }^{16}$ Slovak messianism (authors like Peter Kellner-Hostinský, Samuel Bogdán Hroboň, but also Hodža and Štúr in his final book) is a form of Christian, theosophical conception (based on irrationalism and religious mysticism) developed in the 19th century. As Dupkala states, it can be classified as a specific conception of the (escatological) philosophy of history (Dupkala 1998). Slavic utopianism is based primarily on Herder's idea of the peace-humanization mission of the Slavs (Herder 1941) and on the ideas of Russian Slavophiles.

${ }^{17}$ Hurban was originally a follower of Hegel, he was also inspired by Fichte; later, under the influence of Polish messianists and Schelling's philosophy, it became messianist (Dupkala 2000: 49). Hodža also followed Schelling, Herder and Baader. He was a critic of Hegel (arguing with 'Svetoduch' (Eng. 'The Spirit of The World') in his poems) and the Enlightenment (Dupkala 2000: 60-65). 


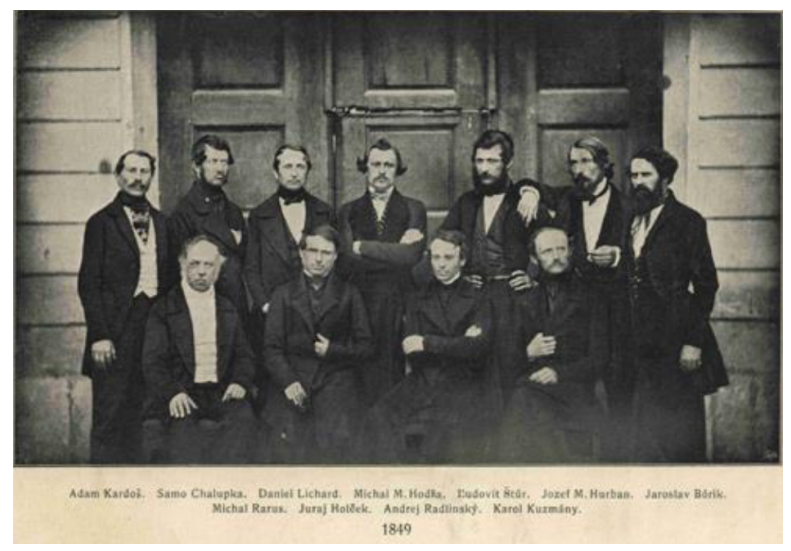

Img. 3. Štúr's group in 1949. The source is slovackizavod.org

Time, however, revolves without ceasing, and as these nations inhabit for the most part the finest country of Europe... these now deeply sunk, but once industrious and happy people will at length awake from their long and heavy slumber, shake off their chains of slavery, enjoy the possession of their delightful lands...' Book XVI, Ch. IV (Herder 2016). In the context of Hegel's philosophy of history, thinkers were inspired by the demand for recognition of the state as a basic precondition for emancipation (therefore Štúr preferred connection with Russia as a realistic alternative at the time of national oppression, because Slovak independence was not possible in monarchy). Slovak national thinkers gained knowledge of Hegel's philosophy mainly during the studies in Germany (Štúr has been studying in Germany, from 1838 to 1840 under the old hegelians like R. Ropell, J. E. Erdmann and J. Schaller; Dupkala 2006: 109). According to the situation and political position of Slovaks in the 19th century, the idea of Hegel's philosophy of history was transformed into the specific Slovak concept. Štúr states: 'We can only build on the philosophy of the great thinker Hegel ... We will rework this philosophy, but first we must cope with it firmly...' (Štúr 1956: 156).

\section{ŠTEFAN MARKO DAXNER, JÚLIUS FEJEŠ AND THE INTERNATIONAL CONTEXT OF SLOVAKS IN POLITICAL PHILOSOPHY}

According to the logic of this text, pro-national philosophers are followed by philosophers who came close to the international context. Looking for the deeper international roots in the national movement, they can be found both in the message of Janko Král'(Vongrej 1989) (but not in a philosophical way, more in literature and in a political context) and in works and ideas of Mikuláš Dohnány, co-author of the work about the Slovak uprising in 1848 (Dohnány, Štefanovič 1988). Hajko recalls that Dohnány has always fought against the fear of non-national cultures and preferred inspiration and creative impulsions from other nations (Hajko 2018). Ján Francisci, a poet, novelist, translator, publicist and politician, had very similar ideas. According to Hajko, who analysed the philosophical legacy of Francisci's work, reader can find (only in an intuitive form) ideas about the great future of the Slavs, Herderian-Messianic ideas and objective ideas about the future of humanity. Francisci wrote about the spirit of the nation and the spirit of humanity, which manifests itself through the activity of a particular nation in which it is objectified.

However, looking for the deeper roots of international thinking, it is necessary to go back to the period of enlightenment, when the thinker Ján Feješ has been working on reworking 
of Rousseau’s social philosophy. J. Feješ (Feješ 1981), a Slovak publicist and lawyer of the enlightenment period, is one of the first international-minded philosophers in Slovakia. Another international minded philosopher came many years after him - a prominent Slovak philosopher and lawyer Štefan Marko Daxner (Daxner 1958). Both thinkers interpreted Rousseau's social and political philosophy in a new international way (they did not accept it fully, only partially). Rousseau's concept was adapted to the Slovak social and political situation. R. Dupkala states that it was Feješ who transformed the ideas coming from the French enlightenment (reflections of the origin and development of human society, the natural state of man, the state and civil society, the natural rights of man and so on...) (Dupkala 2006: 71) into the Slovak context. Slovak philosophers adopted reflections on the state from the French tradition, however, they rejected the ideas of materialism and atheism. Feješ agrees with Rousseau that man is born free and freedom follows from human nature: 'The goal of the state is security. Without security, it is not possible to apply civil rights and property cannot be used and contact between people and improvement of humanity is not possible too... A characteristic feature of humanity is the development and recognition of human rights... The state strengthens these rights and protects them with power... Human can become a real human being only in the state... Who is a human can and also must be a citizen' (Feješ 1981: 364).

Slovak philosopher D. Hajko studied the philosophical dimension of Štefan Marko Daxner works and analysed his philosophical conception in the books The Philosophical Returns and Visions (Hajko 2001) and The Slovak Provocations (Hajko 2018). Hajko states that Daxner's socio-philosophical and philosophical legal views 'always had a strong moral background and merged into the idea of a humanistic meaning that the rights and freedoms of a nation are analogous to the rights and freedoms of the individual' (Hajko 2001: 17).

Hajko further reminds that Daxner did not look for an alternative in escalating conflicts, but in a mutual agreement between the nations of monarchy (in the confirmation of the social contract). He preferred an agreement between nations to guarantee equality of people over the law and the natural right of man in the spirit of the principle of equality of nations (eternal natural law). Daxner applied his ideas to an important historical and legal document - The Memorandum of the Slovak Nation (1861) (see Valco et al. 2020), which he himself initiated and created. Š. Polakovič, Slovak philosopher, writes in this context the following: 'Daxner's ideas were accepted with a little changes in the final formulation of the Memorandum of the Slovak Nation in 1861. He was the author of basic structure of this document. As a clever lawyer, he expressed the main principles of peaceful coexistence between nations. In this principles is his merit and spiritual greatness...' (Polakovič 1944: 107).

D. Hajko considers Daxner and Štúr to be the first Slovak philosophers ever. Hajko described Daxner as one of the first Slovak 'Europeans': 'Daxner is an extraordinary figure in Slovak history... He, one of the greatest fighters for the rights of Slovaks, came from a family from Switzerland, he married a Hungarian wife ... The aristocrat who supported the rights of ordinary people... Daxner built his human and cultural identity on higher principles. Daxner wanted to order these principles to Slovaks...' (Hajko 2019).

\section{CONCLUSIONS}

The Slovak Republic is a sovereign, democratic state governed by the rule of law (The Constitution of the Slovak Republic (Slovak: Ústava Slovenskej republiky).

Kollár and Štúr, who fought together, but paradoxically also one against each other, in the sphere of ideas about the future (about the future of official language and the future of state), became the cornerstone of Slovak philosophy in social, political dimension and in the dimension 
of philosophy of history. The Constitution of the Slovak Republic (1993) is a partial implementation of the ideas that thinkers of the 19th century presented in their works. Slovaks (in the 19th century) did not have their own state, official accepted language and political rights (as a nation). Therefore, the visions of national thinkers of the 19th century seemed naive and unrealizable in political practice. ${ }^{18}$ Thanks to The Constitution of the Slovak Republic, the national utopia of thinkers of the 19th century is now a reality (Slovaks have their own officially recognized language, own institutions, political and social rights). On the basis of the national-emancipation struggle, the state language, national rights and the whole philosophical tradition of national philosophy originated. Important political documents (like Requests of the Slovak Nation - 1848, Memorandum of the Slovak Nation - 1861) and Slovak cultural institutions (the first Slovak grammar schools established in 1861 and the main Slovak cultural institution - Matica slovenská established in 1863) were also created on this ideological basis. The Constitution of the Slovak Republic is linked with Štúr (Slovakia as an independent state), but in the geopolitical context, Štúr's vision of political unification of the Slavic nations has not been fulfilled currently (hypotactically with the exception of the 20th century - the Soviet Union).

On the other hand, Štúr's idea of the political unification of the Slavic nations, due to their fragmentation (the influence of historical development in the 20th century), is once again becoming a utopia of the future. But Kollár's conception of the cultural unity of the Slavs through the literature and art is more fulfilled. However, the existence of the current Slovak constitution is the proof that the best ideas of 19th century thinkers found its application in practical socio-philosophical and political praxis.

\section{ACKNOWLEDGEMENTS}

We are grateful to Mgr. Gabriel Kul'bak from the University of Prešov for help with translation and corrections, and Dr. Tomas Kačerauskas for publishing this study.

Received 23 October 2020

Accepted 19 November 2020

\section{References}

1. Bilasová, V.; Dupkala, R.; Žemberová, V. 2004. Fenomén Slovanstva I: jeho filozofické, teologické, politologické a literárnohistorické reflexie na Slovensku. Prešov: Filozofická fakulta v Prešove.

2. Bodnár, J. 1987. Dejiny filozofického myslenia na Slovensku I. Bratislava: VEDA.

3. Brock, P. 2012. Slovenské národné obrodenie 1787-1847. Bratislava: Kaligram.

4. Clementis, V. 1946. Slovanstvo kedysi a teraz. Praha: Orbis.

5. Daxner, Š. M. 1958. V službe národa. Bratislava: SVKL.

6. Dohnány, M.; Štefanovič, S. 1988. História povstania slovenského z roku 1848 (History of the Slovak Uprising of 1848). Bratislava: Tatran. Available at: https://zlatyfond.sme.sk/dielo/1458/Dohnany_ Historia-povstania-slovenskeho-z-roku-1848/bibliografia

7. Dupkala, R. 1998. Úvod do filozofie dejín: (Príspevok k problematike 'historiosofie'). Bardejov: Fotopress.

8. Dupkala, R. 2000. Štúrovci a Hegel. Prešov: Manacon.

9. Dupkala, R. 2003. O mesianizme: filozofické reflexie. Prešov: Slovacontact.

10. Dupkala, R. 2006. Reflexie európskej filozofie na Slovensku. Prešov: Impreso.

11. Dupkala, R. 2009. 'Filozofovanie na Slovensku: Reflexie a súvislosti. K problematike receptívnosti filozofického myslenia na Slovensku', Filozofia 64(6): 552-559. Available at: https://www.klemens.sav.sk/ fiusav/doc/filozofia/2009/6/552-559.pdf

${ }^{18}$ Slovakia was part of the Habsburg Monarchy, the Austrian Empire and later the Austro-Hungarian Empire. Only a part of Slovakia was in the past part of Great Moravia, which was a West Slavic state existing between 833 and the beginning of the 10th century. After the end of Great Moravia (The Principality of Hungary), there were no Slovak rights or respect for their nationality and cultural rights. 
12. Dupkala, R.; Perný, L. 2020. 'Nedokončené je horšie ako nezačaté (Interview between Lukáš Perný and Rudolf Dupkala)', Slovenské národné noviny 34. Available at: https://snn.sk/news/nedokoncene-je-horsie-ako-nezacate/

13. Feješ, J. 1981. 'Zaslúžil sa o ludstvo viac ženský či mužský rod?', in Antologie z dějin českého a slovenského filozofického myšlení. Praha: Svoboda.

14. Gluchman, V. 2020. 'Jan Kollar's Thoughts on Capital Punishment', Studies in Christian Ethics.

15. Hajko, D. 2007. Filozofické návraty a vizie. Bratislava: Iris.

16. Hajko, D. 2018. Slovenské provokácie. Bratislava: Vydavatelstvo Spolku slovenských spisovatelov.

17. Hajko, D. 2019. Noc hladania, dni radosti (Nad dolnozemskou literatúrou). Báčsky Petrovec: Slovenské vydavatel'ské centrum.

18. Hegel, W. G. 1989. Phänomenologie des Geistes. Frankfurt: Suhrkamp.

19. Herder, J. G. 1941. Vývoj lidskosti. Praha: Jan Laichter.

20. Herder, J. G. 1968. Reflections on the Philosophy of the History of Mankind. Chicago: University of Chicago Press.

21. Herder, J. G. 2016. Outlines of a Philosophy of the History of a Man. London: Luke Hapfart.

22. Hodža, M. M. 1847. Dobruo slovo Slovákom, súcim na slovo. Levoči: Tlačom J. Werthmüllera a Sina. Available at: https://zlatyfond.sme.sk/dielo/1274/Hodza_Dobruo-slovo-Slovakom-sucim-na-slovo/1

23. Hollyý, J. 1950. Dielo Jana Hollého: Sláv. Bájosloví. Trnava: Spolok sv. Vojtecha. Available at: https://zlatyfond.sme.sk/dielo/921/Holly_Slav/bibliografia

24. Hollý, J. 1999. 'Svatopluk', in Dielo II. Bratislava: Tatran. Available at: https://zlatyfond.sme.sk/dielo/10/ Holly_Svatopluk/bibliografia

25. Hurban, J. M. 1847. 'Editorial note by Hurban about article of E. Geromett (Slavic Affection for Freedom)' [Redakčná poznámka J. M. Hurbana k článku E. Geromettu Slovanou náklonnost̉ ku slobodě], in Slovenskje pohladi (Slovak Views) 2.

26. Hurban, J. M. 1944. Spisy Jozefa Miloslava Hurbana. Martin: Matica slovenská. Available at: https://books. google.sk/books/about/Spisy_Jozefa_Miloslava_Hurbana_L_udovit.html?id=DGNLAAAAMAAJ\& redir_esc $=$ y

27. Kollár, J. 1954. O literárnej vzájomnosti medzi rozličnými kmeňmi a nárečiami slovanského národa. Bratislava: Vydavatel'stvo SAV. Available at: https://zlatyfond.sme.sk/dielo/307/Kollar_O-literarnej-vzajomnosti/1

28. Kollár, J. 1863. Spisy Jána Kollára. Díl čtvrtý. Praha: Nákladem knihkupectví I. L. Kober.

29. Kollár, J. 2001. Dielo I. Básne. Bratislava: Slovenský Tatran.

30. Kollár, J. 2018. Dcéra Slávy. Bratislava: Perfekt. Available at: https://zlatyfond.sme.sk/dielo/142/Kollar_ Slavy-dcera/1

31. Kraus, M. 1984. Zažiaril meteor. Bratislava: Slovenský spisovatel’.

32. Maxwell, A. 2018. 'Effacing Panslavism: Linguistic Classification and Historiographic Misrepresentation', Nationalities Papers - The Journal of Nationalism and Ethnicity 46(4): 663-653.

33. Nedashkovskaya, N. I.; Myagkov, G. P. 2017. 'Polemika vokrug traktata L. Štura "Slavyanstvo i mir budushchego": romantizm i nigilizm v diskurse proyektov slavyanskogo national'nogo vozrozhdeniya XIX veka', Uchenye Zapiski Kazanskogo Universiteta. Seriya Gumanitarnye Nauki 159(4): 856-871. Available at: https:// kpfu.ru/uz-eng/hum/archive/polemics-around-1-352t250rs-essay-39slavdom-and_334351.html

34. Novomeský, L. 2019. '150 rokov od úmrtia Štefana Moysesa: Davista Ladislav Novomeský o odkaze Štefana Moyzesa', DAV DVA. Available at: https://davdva.sk/150-rokov-od-umrtia-stefana-moysesa-davista-ladislav-novomesky-o-odkaze-stefana-moyzesa/

35. Odlerová, E.; Hýllová, K. 2019. 'The Role of Faith in Forming the Slovak History the Case of Ludovit Štúr', European Journal of Science and Theology 15(5): 11-18.

36. Pichler, T. 2006. "West" and "East" in Ethnic Romanticism of Ludovít Štúr', Filozofia 61(10): 794-803. Available at: https://www.klemens.sav.sk/fiusav/doc/filozofia/2006/10/794-803.pdf

37. Polakovič, Š. 1944. Začiatky slovenskej národnej filozofie. Bratislava: Vlastný náklad.

38. Szacki, J. 1971. Utopie. Praha: Mladá fronta.

39. Šafárik, P. J. 1963. Dejiny slovanského jazyka a literatúry všetkých nárečí (Geschichte der slawischen Sprache und Literatur nach allen Mundarten). Bratislava: Vydavatel'stvo Slovenskej akadémie vied.

40. Štúr, L. 1956. Dielo v piatich zväzkoch. Zväzok II. Bratislava: SVKL.

41. Štúr, L. 1993. Slovanstvo a svet budúcnosti. Bratislava: Slovenský inštitút medzinárodných štúdií. Available at: https://zlatyfond.sme.sk/dielo/1496/Stur_Slovanstvo-a-svet-buducnosti/bibliografia 
42. Štúr, L. 2015. Slovanstvo a svet budúcnosti. Nitra: Nitrava.

43. Timura, V. 2018. Generácia V̌̌eslávie. Bratislava: Nitrava.

44. Ustava Slovenskej republiky (The Constitution of the Slovak Republic). 2017. Bratislava: Poradca s.r.o.

45. Valco, M.; Dancak, P.; Shikh, E. V.; Polevaya, M. V.; Shukshina, L. V. 2020. 'Philosophical Roots of the Slovak National Revival Movement in Mid-19th Century: A Case Study on the Memorandum Events of 1861 in Turciansky Sv. Martin', XLinguae 13(3): 228-240.

46. Várossová, E. 1969. 'Zmysel dejín a naše dejiny', Filozofia 24(3): 3-33.

47. Veselá, P. 2016. 'Utopian Studies in the Czech and Slovak Republics', Utopian Studies 27(3): 431-440.

48. Vongrej, P. 1989. Syn sveta. Bratislava: Tatran.

49. Ždárský, G. 1924. Obsahy z československé beletrie doby nové. Praha: J. Bačkovský.

LUKÁŠ PERNÝ

\section{Slovakų utopizmo ištakos ir 1848-ųjų utopinès sąvokos}

\section{Santrauka}

XIX a. slovakų utopizmas (ir specifinè sociopolitiné filosofija) yra unikali tema filosofiniam tyrimui, kuris ypač gali praversti gilinantis ị tarptautinį kontekstą. Šio tyrimo tikslas - pasitelkus lyginamajji metodą sukurti bendrą XIX a. utopinių sąvokų Slovakijoje apžvalgą ir išryškinti jų pritaikomumą šiandien. Studiją sudaro dvi temos: pirma, vokiečių istorijos filosofijos (Hegelio, Herderio, Schellingo) įtaka sociopolitinèms tautos sampratoms ir vokiečių filosofinès ịtakos sintezè slovakų filosofijoje (Kolláras, Šafárikas, Štúras); antra, sociofilosofinès sąvokos, susijusios su slovakų vaidmeniu tarptautiniame kontekste (Feješas, Daxneris). Tautinè slovakų utopija, kultūrinio ir socialinio slovakų igalinimo jų pačių suverenioje valstybèje pavidalu, iš dalies materializavosi XX a. (issteigiant Čekoslovakiją ir vèliau nepriklausomą Slovakijos Respubliką). Slovakijos Respublikos Konstitucija yra ịrodymas, kad utopinès socialinès vizijos, iš pradžių (XIX a.) atrodžiusios naivios ir neigyvendinamos, $\mathrm{XX}$ a. buvo realizuotos politineje praktikoje.

Raktažodžiai: socialinė filosofija, politinė filosofija, slovakų utopizmas, Všeslávie karta, Štúro grupè, JánKollár, Pavol Jozef Šafárik, L’udovít Štúr, Ján Feješ, Štefan Marko Daxner 